\title{
Relational Ties in Emerging Markets: What Is Their Contribution to SME Growth?
}

Natalya Totskaya

P rior studies argue that social capital is vital for firm growth. Adding to this line of research, this paper provides more evidence regarding the contribution of bonding and bridging social ties to various aspects of small-l and medium-sized enterprise (SME) development. Building on the original data from Russia, this paper investigates the effects of firm-internal and firm-external relational ties on SME performance and geographic expansion. The findings indicate that horizontal bridging ties facilitate specific strategies of SME growth. Thus, this paper supports prior research conducted in the Asian context, and allows for extending the outcomes of bonding and bridging social capital into broader institutional settings. In addition, this study raises the question of relationship between the composition of social capital and distinct organizational characteristics of SMEs. Finally, the paper discusses the implications for future research, and outlines some practical recommendations for SMEs operating in emerging markets.

Keywords: bonding social capital, bridging social capital, SMEs, emerging markets, growth

Social capital research has been of great interest to management scholars for many years. Yet the great number of studies have been conducted in the context of large enterprises and developed economies (Burt, Hogarth, \& Michaud, 2000; Florin, Lubatkin, \& Schulze, 2003; Stam \& Elfring, 2008). Researchers who focused outside of developed economies were mainly interested in studying institutional realities of Asian countries (Gao, Sung, \& Zhang, 2012; Park \& Luo, 2001; Tung \& Chung, 2010; Xu, Huang, \& Gao, 2012). This study adds to the body of research on non-Asian emerging markets, providing more insight into the role played by social capital in transition economy of Russia. The main goal is to clarify the relationship between bonding and bridging social capital of SMEs and their growth.

When speaking of growth we intend to address both qualitative and quantitative changes in firm behavior and outcomes following Penrose (1959). Penrose's broad view of the phenomenon of firm growth (1959) allows for considering SME growth as SME development. Firm-internal, qualitative changes, such as formalization of SME's activities and practices may be accompanied by quantitative changes, such as an increase in SME output or size (Torrès \& Julien, 2005). This multi-dimensional process implies that growth may have various sources and effects, and firms may use a combination of growth options (Davidsson \& Wiklund, 2000). Growth may be related to firm or industry life cycles; it may require changes in organizational processes, or call for behavioral adjustments on the part of management and employees. Firm's growth, in its broad sense, is shaped by the creation and use of various social, hierarchical, and market relations that may be firm-internal or firm-external, and together they comprise firm social capital.

This study builds upon Adler \& Kwon's (2002) approach, and aims to add to our understanding of bonding (firm-internal) and bridging (firm-external) relations. These two facets of social capital will be tested at a firm level, for specific class of firms (SMEs), and in the distinct institutional setting of Russia. Research questions addressed in this study: 1) is there a link between the structure bonding and bridging social capital and SME growth?; and 2) does the nature of SMEs encourage development of specific type of social capital?

To answer these questions, we first review prior literature on the theoretical foundations of social capital research, and the role of social capital in firm behavior. Second, we'll discuss the proposed relationship between bonding and bridging social capital and SME growth. The following section will present research methodology, analytical procedures, and results of hypotheses testing. And finally, the discussion section will review the main findings, implications, and limitations of this study.

\section{Theoretical Background: Social Capital Perspective and Firm Growth}

Theoretical foundations of social capital include individual, collective, and mixed-level perspectives (for review see Payne, Moore, Griffis, \& Autry, 2011). As noted by Adler \& Kwon (2002), definitions and conceptualizations of social capital vary, and they include external and internal characteristics of actors involved in creation and appropriation of social capital. For instance, Burt (1997; 2000) and Coleman (1988) approach social capital from the network perspectives, 
looking at structural holes and network closure, respectively; Nahapiet \& Ghoshal (1998) focus on multiple dimensions of social capital; Adler \& Kwon (2002) offer a multilevel model of external and internal relations contributing to creation of social capital. In their view, bonding social capital represents "collective actors' internal characteristics" (Adler \& Kwon, 2002, p. 21); and bridging social capital is "a resource located in the external linkages of a focal actor" (Adler \& Kwon, 2002, p. 21).

Prior research has recognized the value of organizational social capital as an embedded resource that "comprises both the network and the assets that may be mobilized through that network" (Nahapiet \& Ghoshal, 1998, p. 243). The notion of embeddedness (Granovetter, 1992) is widely used in social capital literature, allowing researchers to make a distinction between different types of social capital. Bridging social capital refers to configuration of linkages between actors (Granovetter, 1992; Nahapiet \& Ghoshal, 1998). Bonding social capital refers to the type of relations that are developed through the history of interactions (Granovetter, 1992; Uzzi, 1996; 1997).

Numerous studies have looked at the effects of bonding and bridging social capital (see Figure 1). Diverse institutional settings included Asia and Africa (Abban, Omta, Aheto, \& Scholten, 2013; Park \& Luo, 2001; Sako 1992), North America and Western Europe (Burt, Hogarth, \& Michaud, 2000; Uhlaner, Matser, Berent-Braun, \& Flören, 2015), Central and Eastern Europe (Gittins, Lang, \& Sass, 2015). Organizations in the focus of social capital research included business groups (Cardoza \& Fornes, 2011; Dyer, 1996), SMEs (Gao et al., 2012; Iturrioz, Aragón, \& Narvaiza, 2015), and public sector organizations (Leana \& Pil, 2006). Figure 1 presents a summary of findings in social capital research.

Yet the distinction between bonding and bridging social capital at a firm level remains vague. Woolcock (1998) synthesized the effects of these two types of social capital on individual (micro) and societal (macro) levels of analysis, bringing bonding and bridging social capital together in one framework of economic development. His framework highlights both opportunities and limitations of bonding and bridging social capital combinations. Woolcock suggested that the need for internal connections decreases as embeddedness in external networks increases. Thus, for organizations as units of analysis, Woolcock's ideas may translate into growth strategies that are shaped by firm-internal bonding relations, and by the system of bridging linkages with external environment.

The nature of SMEs places more emphasis on social capital as a valuable resource; and thus social

\begin{tabular}{|c|c|}
\hline Bridging Social Capital & Bonding Social Capital \\
\hline \multicolumn{2}{|c|}{ Benefits } \\
\hline $\begin{array}{l}\text { Provides access to resources } \\
\text { (Nahapiet \& Ghoshal, 1998); } \\
\text { helps to overcome strategic and } \\
\text { resource disadvantages (Park \& } \\
\text { Luo, 2001) }\end{array}$ & $\begin{array}{l}\text { Helps firm resources recombi- } \\
\text { nation (Assudani, 2009; Galunic } \\
\text { \& Rodan, 1998) and improves } \\
\text { firm survival (Pennings, Lee, \& } \\
\text { van Witteloostuijn, 1998) }\end{array}$ \\
\hline $\begin{array}{l}\text { Facilitates economic transactions } \\
\text { (Granovetter, 1973; McMillan \& } \\
\text { Woodruff, 1999; van Staveren \& } \\
\text { Knorringa, 2007) }\end{array}$ & $\begin{array}{l}\text { Facilitates actions and transac- } \\
\text { tions, lowers transition costs } \\
\text { (Cardoza \& Fornes, 2011; Cole- } \\
\text { man, 1988) }\end{array}$ \\
\hline $\begin{array}{l}\text { Facilitates exploratory behavior } \\
\text { and innovations (Coviello, 2006; } \\
\text { Iturrioz et al., 2015) }\end{array}$ & $\begin{array}{l}\text { Helps entrepreneurs to establish } \\
\text { their business (Gittins, Lang, \& } \\
\text { Sass, 2015; Kreiser, Patel, \& } \\
\text { Fiet, 2013; Peng, 2004) and in- } \\
\text { ternationalize (Ma \& Wang } \\
\text { 2012) }\end{array}$ \\
\hline $\begin{array}{l}\text { Access to new information and } \\
\text { opportunities (Burt, 1997; } \\
\text { Cardoza \& Fornes, 2011; Gran- } \\
\text { ovetter, 1973; Peng, 2004; } \\
\text { Woolcock, 1998; Zahra et al., }\end{array}$ & $\begin{array}{l}\text { Fosters reciprocity, coordina- } \\
\text { tion, help, and cooperation } \\
\text { (Dyer, 1996; Macneil, 1980; } \\
\text { Pearson, Carr, \& Shaw, 2008; } \\
\text { Peng, 2004; Sako, 1992; Uzzi, }\end{array}$ \\
\hline $\begin{array}{l}\text { Allows for more cooperation } \\
\text { (McMillan \& Woodruff, 1999) }\end{array}$ & $\begin{array}{l}\text { Stimulates coherent actions and } \\
\text { common vision (McCallum \& } \\
\text { O'Connell, 2009; Uhlaner et al., }\end{array}$ \\
\hline $\begin{array}{l}\text { Helps leveraging new knowledge } \\
\text { and resources (Park \& Luo, } \\
\text { 2001; Yli-Renko, Autio, \& } \\
\text { Tontti, 2002; Zahra et al., 2007) }\end{array}$ & $\begin{array}{l}\text { Helps sharing and transferring } \\
\text { knowledge (Gao et al., 2012; } \\
\text { Lowik, Rossum, Kraaijenbrink, } \\
\text { \& Groen, 2012; Uzzi, 1996; Yli- }\end{array}$ \\
\hline $\begin{array}{l}\text { Improves performance } \\
\text { (Batjargal, 2007; Koka \& Pres- } \\
\text { cott, 2002; Park \& Luo, 2001; } \\
\text { Peng \& Luo, 2000) }\end{array}$ & $\begin{array}{l}\text { Improves organization out- } \\
\text { comes (Abban et al., 2013; } \\
\text { Leana \& Pil, 2006) }\end{array}$ \\
\hline \multicolumn{2}{|c|}{ Costs } \\
\hline $\begin{array}{l}\text { Conformity pressures if a net- } \\
\text { work of relations is large (Burt, } \\
\text { 1997) }\end{array}$ & $\begin{array}{l}\text { Limits developmental options } \\
\text { by locking within group bound- } \\
\text { aries (Uzzi, 1997; Woolcock, } \\
\text { 1998) }\end{array}$ \\
\hline
\end{tabular}

Figure 1. The Effects of Bonding and Bridging Social Capital

capital can represent a valuable asset in managing SMEs daily activities, and in planning their developmental efforts. It is widely accepted that SMEs are more vulnerable to unfavorable changes in market conditions because of their limited resources, and simplified management systems. A number of studies have demonstrated that smaller firms have less slack resources than larger players (Penrose, 1959, Oviatt \& McDougall, 1994; Lu \& Beamish, 2001); and that SMEs use networks to establish their operations and compensate for their lack of resources 
(Gittis, Lang, \& Sass, 2015; Julien, 1993; Kreiser, Patel, \& Fiet, 2013). Empirical studies suggest that SMEs from emerging markets rely on social networks even more as they try to 1) compensate for their scarce resources and deficient external environments, and 2) gain access to new markets and business opportunities (Chen \& Chen, 1998; Gittins, Lang, \& Sass, 2015; Tung \& Chung, 2010; Zhao \& Hsu, 2007).

\section{Theory Development}

\section{The Value of Social Capital for SMEs in Emerging Markets}

Researchers agree that social capital embedded in relationships is more important in emerging markets where formal institutional frameworks are weak, uncertainty is high, and information is highly fragmented (De Clercq, Danis, \& Dakhli, 2009; Peng \& Luo, 2000; Xin \& Pearce, 1996). It has been argued that extensive networking exemplified in vertical ties can provide emerging markets firms with increased access to complementary resources, technologies, competences, and knowledge (Li, Zhou, \& Shao, 2009). In addition, various social ties can improve adaptability to environmental uncertainties (Tallman, Jenkins, Henry, \& Pinch, 2004; Peng \& Heath, 1996; Xin \& Pearce, 1996). Some authors (Park \& Luo, 2001; Xu, Huang, \& Gao, 2012) stated that the development of institutional ties between firms and government officials was led by environmental uncertainty, and was based on strong interpersonal relations. Hence, in the context of emerging markets, the creation of firmexternal, bridging capital is significantly affected by the presence of bonding capital.

In such an environment, strong relational ties that indicate a built-in ascribed trust and sharing of fine-grained information seem to carry higher value to an SME than weak ties (Khanna \& Palepu, 1997; Peng \& Heath, 1996; Peng \& Luo, 2000). Strong ties allow small companies to capitalize on close social relations, without carrying the costs and uncertainties of arm's-length transactions (Zhao \& Hsu, 2007); and mobilize firm-internal capabilities for knowledge sharing, innovation and resource recombination (Galunic \& Rodan, 1998). Contracts and agreements that are based on ascribed trust, reciprocity, and other in-group relational attributes allow organizations to carry on various partnerships (Dyer, 1996; Macneil, 1980; Sako, 1992), and increase their overall market competence (Wu, Sinkovics, Cavusgil, \& Roath, 2007).

In emerging markets, external connections built upon strong ties provide a firm with better access to the market ( $\mathrm{Li}$ et al., 2009), more financial resources (Leuz \& Oberholzer-Gee, 2006), government con- tracts, information, and updates on upcoming changes in regulations (Yiu, Lau, \& Bruton, 2007). The latter point implies that vertical external ties may be especially valuable for firms seeking to grow into new domestic and international markets. Prior studies imply that kinship-based bonding relations are indeed reflected in inter-organizational networks, and that the majority of bridging ties are in fact strong ties (Peng, 2004; Zhao \& Hsu, 2007). However, these results have not been tested outside of the Asian context. Thus, while the value of bonding capital is well established in prior research, this capital is measured not at a firm level, but rather at a group or network level.

It seems that, at an organizational level the relative value of bonding and bridging social capital remains somewhat open for discussion. With a growing number of studies dealing with relational ties and their effects on firm behavior and outcomes in emerging and transition countries, the distinction between bonding and bridging capital at a firm level remains vague. In emerging markets, in-group ties often cross the boundaries of organizations ( $\mathrm{Li}$ et al., 2009; Ma \& Wang, 2012); and thus measuring bonding capital at a firm level does not capture all the implications of close, bonding ties for firm behavior. In turn, the bridging capital of an emerging market firm heavily reflects strong in-group ties, and not arm'slength, weak linkages (Kreiser, Patel, \& Fiet, 2013; Lowik, Rossum, Kraaijenbrink, \& Groen, 2012; Zhao \& Hsu, 2007).

There is some evidence, however, that indicates that even when formal institutions are poorly developed, and the external environment is hostile, small firms still need to rely on arm's-length relations if they are willing to grow beyond local limits, or above a certain size (McMillan \& Woodruff, 2002). Similar conclusions were made by Wright, Filatotchev, Hoskisson, \& Peng (2005) who named a firm's "strategic flexibility," and ability to explore new opportunities as important conditions of survival and successful development in emerging economies. Other researchers indirectly stressed the role of bridging capital by pointing out 1) the benefits of extensive inter-firm networking (Koka \& Prescott, 2002; Spicer, Kogut, \& McDermott, 2000), and 2) the importance of environmental scanning (May, Stewart, \& Sweo, 2000). Taken together, these findings provided suggestions for testing a hypothesis regarding the role of bridging social capital in SME growth that may take a firm beyond its usual comfort zone, and beyond local markets.

Hypothesis 1.1: Bridging capital of SMEs operating in emerging markets will be positively associated with an SME's growth outside its local market. 
The extant literature is inconclusive regarding the effects of bonding ties on organizational outcomes. The main focus of researchers has been on the benefits derived from bonding capital such as better firm survival capability (Pennings, Lee, \& van Witteloostuijn, 1998) or improved performance (Cooke, Clifton, \& Oleaga, 2005; Leana \& Pil, 2006). The value of bonding relations manifested itself through positive practices and effective firm processes (Collins \& Clark, 2003; Maurer, Bartsch, \& Ebers, 2011). For instance, bonding capital increased mutual understanding and coherent actions (Peng, 2004; McCallum \& O'Connell, 2009), and stimulated tacit knowledge acquisition (Lowik et al., 2012), knowledge exchange and resources transfer (Pearson et al., 2008; Uzzi, 1996; Yli-Renko, Autio, \& Tontti, 2002). In the case of Chinese SMEs bonding capital allowed for capability building (Gao et al., 2012) and contributed to overcoming the internal barriers to growth in a firm (Cardoza \& Fornes, 2011). Hence, strong bonding relations are expected to contribute to SME effective functioning that will be reflected in performance.

Hypothesis 1.2: Bonding capital of SMEs operating in emerging markets will be positively associated with SME performance.

\section{Social Relations and the Nature of SMEs}

Previous discussion suggested that the environmental conditions of emerging markets might have played an important role in defining SME social capital. However, some specific attributes of SMEs themselves may encourage firms to place more emphasis on creating more bonding or more bridging capital at a firm level. With many studies having been carried out into SMEs, there is still a lack of agreement on the theoretical conceptualization of SMEs. In entrepreneurship research, SMEs are often associated with an individual entrepreneur and his/ her behavior (Baker \& Nelson, 2005; Lumpkin \& Dess 1996; Wiklund \& Shepherd, 2003). In the field of international business studies, SMEs are often seen as innovative, actively internationalizing firms (McDougall, Shane, \& Oviatt, 1994; Zahra, Neubaum, \& Naldi, 2007). A less known theoretical perspective on the nature of SMEs has been developed in the French literature. This literature deals with the specificity of SMEs in terms of their formal organization and management (D'Amboise \& Muldowney, 1988; Curran, 2006; Julien, 1993; 1998; Torrès \& Julien, 2005).

The "small business concept," introduced by the abovementioned authors, fits well with the notion of social capital. It emphasizes the special nature of
SMEs through SME management, and hence through internal relations within a firm, as well as the external relations with other actors. In short, there are two major types of SMEs: 1) "traditional" small business; and 2) "anti-small business," also known as "denatured" small business (Julien, 1993; 1998). Julien has synthesized some important characteristics of "traditional" small businesses into one framework. First, he pointed out that traditional SMEs were engaged in informal, direct, and simple management practices and systems of information collection and exchange. Second, he argued that they preferred direct contact or dialogue when communicating internally and externally. Third, he stated that traditional SMEs used informal networks to stabilize their position in the external environment.

However, behavioral diversity among SMEs puts some of them outside (or on the boundaries) of the traditional small business concept (Messeghem, 2003; Torrès \& Julien, 2005). For instance, some SMEs adopt multiple product lines usually associated with large companies and use complex planning systems; they are fast on learning and innovation, and they compete internationally. "Although the anti-small business has the attributes of a large business, it is still small in size. In some ways, the anti-small business is a miniature big business" (Torrès \& Julien, 2005, p. 363).

Torrès \& Julien (2005) also referred to prior research and identified some environments that can lead to SME denaturing, including: 1) globalization of markets; 2) participation in alliances and business groups; and 3) adoption of modern data and quality management systems. Such factors can cause SMEs to become more explicit in their management procedures, as well as less centralized and less informal. From the growth perspective, denaturing represents changes in the nature of SMEs, and hence exemplifies what Penrose (1959) refers to as "internal changes," or the qualitative growth of a firm.

Thus, it is reasonable to expect that in emerging markets SMEs will be affected by the denaturing factors listed above; and hence, as a result of qualitative growth, the changes in SMEs' nature will be reflected in specific features of SME social capital. For instance, some SMEs may face the need to develop more bridging connections to be able to capture more opportunities, maintain complex strategies and keep up higher business standards than their "traditional" counterparts.

Nowadays globalization affects countries in all parts of the world and information management systems have become standard for any business organization of any size. Also, it is well known that business groups dominate emerging and transition economies around the world (Khanna \& Palepu, 1997). Hence 
factors that can create an SME denaturing environment are as present in emerging countries as in mature ones. For example, SMEs that are members of business groups may lose at least part of their independence and unique identity in terms of their strategy formulation, their management system, and their choice of partners. So they will rely less on the bonding core of their firm, and they will be more open to sharing or delegating some strategic business functions to their business group partners. At the same time, SMEs within business groups need to maintain a wide variety of relationships with other group members, and with external parties that may be geographically and socially distant. As such, they have to develop more bridging ties with other actors; and those ties reflect all kinds of relations, such as: 1) market or social; 2) arm's length, formal or strong, informal; and 3) short or long-term. On the other hand, SMEs that are willing to compete in larger markets may need to adapt to higher levels of competition, product and management requirements. Hence, they will have to connect to greater business communities, carry out more environmental scanning, and become part of various networks.

Overall, denatured SMEs will pay more attention to creating bridging social capital than traditional SMEs in order to be better positioned in the market, and to capitalize on opportunities that arise from their environment. Denatured SMEs will place less emphasis on bonding capital, as they are more explicit in their organization and activities. Thus, the idiosyncratic nature of bonding ties will not fit well into the more formal and open context of denatured SMEs. In the context of this study, it is expected that denatured SMEs will have more bridging ties to their business environment, and less internal bonding ties than their traditional counterparts.

Hypothesis 2.1: Denatured SMEs will exhibit more bridging capital than traditional SMEs.

Hypothesis 2.2: Denatured SMEs will exhibit less bonding capital than traditional SMEs.

\section{Research Methodology}

\section{Sample, Instruments and Procedures}

Sample. SMEs (up to 500 employees) listed in the Novosibirsk City Chamber of Commerce database were contacted by mail; out of 300 firms contacted 71 firms agreed to participate. While the response rate was relatively low (23.6 percent), it was very similar to response rates reported in prior research conducted in emerging markets that ranged from 18 to 26 percent (Batjargal, 2007; Manolova, Brush, Edelman, \& Greene, 2002; Wu, Sinkovics, Cavusgil, \& Roath, 2007). This sample represents a mix of manufacturing firms from high- and low-tech industries (20 and 45 percent respectively). Small businesses of 100 employees or less comprise 78 percent of the sample. The age of the firms ranges between 2 and 79 years, with an average age of 12.2 years. Young firms up to 3 years old comprise 18 percent of the sample, and mature firms of 20 years or more represent 11 percent of SMEs in the study. Out of 71 questionnaires collected, 6 had some missing data that could not be verified or replaced through secondary sources of information. As a result, 6 firms were excluded from the subsequent analysis, and 65 firms comprised the working sample (Table 1).

Instruments and Procedures. The questionnaire was first back-translated, and then pre-tested for measures reliability with 32 graduate MBA students who had a full-time employment in Russian SMEs. Some scales were modified to meet higher reliability requirements. The CEOs of selected firms were contacted to solicit their participation, and as a result, the questionnaires were filled in either by the CEOs themselves, or by one of the top managers, who were well informed of the firm's market development and growth. In addition to questionnaires, the data on firm growth, and industry codes was validated through statistical reports collected by the Russian Federal State Statistics Service. Firm age data was verified through an on-line database of the Federal Tax Service of Russia. Information on

Table 1. Descriptive Statistics of the Working Sample

\begin{tabular}{|l|l|l|l|l|l|}
\hline \multicolumn{7}{|c|}{ Descriptive Statistics } \\
\hline & N & Minimum & Maximum & Mean & Std. Deviation \\
\hline Size (number of employees) & 65 & 1 & 500 & 105.98 & 149.36 \\
\hline Age & 65 & 0 & 79 & 12.22 & 14.240 \\
\hline Industry dummy (1=high & 65 & 1 & 13 & 6.31 & 3.687 \\
\hline
\end{tabular}


SMEs partnerships (including business group affiliation) was verified via firm web pages, booklets and catalogues.

Statistical techniques such as regression analysis and groups comparison were used to examine the main effects between dependent and independent variables.

\section{Measures}

Independent Variables. Structural and relational dimensions of Bonding Social Capital were assessed using multi-item scales. The structural dimension of bonding social capital was measured by social interactions among SME managers, and operationalized as information sharing (Hyatt and Ruddy, 1997; Leana and Pil, 2006). Each of the six items was assessed using a 5-point Likert scale, from 1 (very untrue) to 5 (very true); reported Cronbach's alpha $=0.89$. All items measuring structural dimension of bonding social capital, and their Russian language translations are listed in Table 2.
Relational dimension of bonding social capital was assessed by a six-item measure of trust (Leana $\&$ Pil, 2006). Items were also measured using a 5-point Likert scale; reported Cronbach's alpha $=0.88$ (Table 3).

Bridging Social Capital. The structural dimension of bridging social capital was measured by the density of horizontal and vertical ties. Density (i.e., number) of ties was measured as proposed by Boissevain (1974), by verifying if potentially existing ties do actually exist. Drawing upon analysis of external ties of emerging market firms (Cao, Simsek, \& Zhang, 2010; Xu et al., 2012; Yiu, Lau, \& Bruton, 2007), respondents were asked about eight horizontal and seven vertical ties. Horizontal ties included connections with customers, suppliers, business partners, competitors, professional associations, chambers of commerce, foreign commercial structures, and ethnic associations (diaspora). Vertical ties included connections with banks, financial agencies, govern-

Table 2. Scale-based Measure of Information Sharing

\begin{tabular}{|c|c|c|}
\hline Item & Original items (partially reworded) & Items translated into Russian \\
\hline 1 & $\begin{array}{l}\text { Managers engage in open and honest communication } \\
\text { with one another. }\end{array}$ & Руководители общаются межАу собой честно и открыто. \\
\hline 2 & Managers at this firm have no hidden agendas or issues. & У руководителей нет тайных планов или разногласий. \\
\hline 3 & $\begin{array}{l}\text { Managers share and accept constructive criticisms } \\
\text { without making it personal. }\end{array}$ & $\begin{array}{l}\text { Руководители высказывают и принимают конструктивную } \\
\text { критику, не переходя на Аичности. }\end{array}$ \\
\hline 4 & $\begin{array}{l}\text { Managers discuss personal issues if they affect job } \\
\text { performance. }\end{array}$ & $\begin{array}{l}\text { Руководители обсужАают мичные проблемы, если они } \\
\text { влияют на результаты работы. }\end{array}$ \\
\hline 5 & Managers willingly share information with one another. & Руководители охотно Аелятся информацией Аруг с Аругом. \\
\hline 6 & $\begin{array}{l}\text { Managers at this firm keep each other informed at all } \\
\text { times. }\end{array}$ & $\begin{array}{l}\text { Руководители нашей компании постоянно держат Аруг Аруга } \\
\text { в курсе событий. }\end{array}$ \\
\hline
\end{tabular}

Note: (Hyatt \& Ruddy, 1997; Leana \& Pil, 2006)

\section{Table 3. Scale-based Measure of Trust}

\begin{tabular}{|c|c|c|}
\hline Item & Original items (partially reworded) & Items translated into Russian \\
\hline 1 & I can rely on the managers I work with in this firm. & Я могу положиться на руководителей, с которыми работаю. \\
\hline 2 & $\begin{array}{l}\text { Managers in this firm are usually considerate of one } \\
\text { another's feelings. }\end{array}$ & $\begin{array}{l}\text { Руководители обычно тактично относятся к чувствам Аруг } \\
\text { Аруга. }\end{array}$ \\
\hline 3 & Managers have confidence in one another in this firm. & Руководители доверяют Аруг Аругу. \\
\hline 4 & Managers in this firm show a great deal of integrity. & Руководители проявцяют большую честность. \\
\hline 5 & $\begin{array}{l}\text { There is no "team spirit" among managers in this firm } \\
\text { (reversed). }\end{array}$ & У руководителей нет “Ауха товарищества”. \\
\hline 6 & Overall, managers at this firm are trustworthy. & $\begin{array}{l}\text { В целом, руководители нашей компании заслуживают } \\
\text { доверия. }\end{array}$ \\
\hline
\end{tabular}

Note: (Leana \& Pil, 2006) 
ment agencies, and also federal, regional, municipal, and foreign government structures. Relational dimension was assessed by the strength of horizontal and vertical ties. Strength of ties was measured by their reciprocity. On a dichotomous scale, reciprocity was coded as 1 for close relationships and 0 for distant relationships, following Granovetter (1973).

Dependent Variables. In studies on SME growth, there are several accepted measures of growth, such as sales, assets, employment, market share, and profit (see Davidsson et al., 2007 for review). In this study SME performance was measured as sales growth and expansion beyond local market - as regional growth.

Sales growth was measured as an average percentage of sales increase for 2 years, following Florin et al. (2003), and Zahra, Ireland, \& Hitt (2000). The years 2008 and 2010 were chosen as reference, omitting the sales data reported for 2009, as this was the hardest year of recession for Russian business. Most of the business indicators were significantly lower in 2009 than in 2008 and in preceding years, and eliminating this crisis year from calculations has helped to minimize the negative macroeconomic effects on the dependent variable.

Regional growth was calculated as sales growth weighted by the share of SME revenue from all activities outside their local market, mirroring the measure of international growth widely used in prior studies (Bonaccorsi, 1992; Calof, 1994; Zahra et al., 2007).

Control Variables. Firm age, size, and industry were controlled to minimize the effect of confound- ing variables. Firm age was measured by the number of years as of SME founding, not taking into account changes in firm ownership or name. Firm size was measured as the natural logarithm of the number of employees (full-time), following $\mathrm{Lu} \&$ Beamish (2001). Several industries in the sample were coded as high to medium-technology (1) or medium to low-technology (0), following OECD's (2011) classification of manufacturing industries into categories based on R\&D intensities.

SME denaturing was assessed through business group affiliation following Torrés \& Julien (2005). Using business group affiliation as an indicator of denaturing seems reasonable, provided that the influence of business groups is significant in many emerging markets (Khanna \& Palepu, 1997). In Russian business practices all business groups have to have formal agreements and specific contracts covering the basis of relationships among members. As such, business group membership does reflect a higher level of formality in SME management in comparison with traditional SMEs. SME denaturing was coded as 0 for freestanding firms, and as 1 for members of business groups; thus grouping SMEs into "traditional" and "denatured" categories.

\section{Results}

\section{Relations between SME Social Capital and SME Growth}

Table 4 presents the descriptive statistics and correlation matrix for all the variables in this study. It also provides the results for measures reliability test.

Table 4. Descriptive Statistics and Zero-order Correlations for Variables in the Study

\begin{tabular}{|c|c|c|c|c|c|c|c|c|c|c|c|c|}
\hline List of Variables & Mean & Std. & 1 & 2 & 3 & 4 & 5 & 6 & 7 & 8 & 9 & 10 \\
\hline 1.Information sharing & 2.543 & .791 & 1 & $(.762)$ & & & & & & & & \\
\hline 2.Trust & 2.082 & .633 & $.757^{* *}$ & 1 & $(.801)$ & & & & & & & \\
\hline 3.Density of horizontal ties & 4.310 & 1.310 & -.202 & -.142 & 1 & & & & & & & \\
\hline 4.Density of vertical ties & 2.980 & 1.858 & .140 & $.209 \dagger$ & $.336^{* *}$ & 1 & & & & & & \\
\hline 5.Strength of horizontal ties & 2.520 & 1.480 & -.131 & -.109 & $.633^{* *}$ & .128 & 1 & & & & & \\
\hline 6.Strength of vertical ties & .803 & .306 & -.078 & -.122 & $-.323^{* *}$ & $-.490^{* *}$ & $-.296^{*}$ & 1 & & & & \\
\hline 7.Sales growth & .010 & .139 & -.064 & -.167 & $.213+$ & .099 & $.251^{*}$ & .019 & 1 & & & \\
\hline 8.Regional growth & 1.017 & .299 & -.040 & .013 & $.301^{*}$ & .063 & $.302^{*}$ & -.030 & $.528^{* *}$ & 1 & & \\
\hline 9.LN_Size & 3.78 & 1.649 & .056 & .125 & .163 & $.233+$ & .082 & -.088 & .053 & $.302^{*}$ & 1 & \\
\hline 10.LG_Age & .8999 & .409 & .202 & .156 & .061 & -.077 & .001 & -.073 & $-.239 \dagger$ & .028 & $.381^{* *}$ & 1 \\
\hline
\end{tabular}

Note: $\mathrm{N}=65$; Figures in parentheses are reliabilities of scales.

${ }^{*}$ Correlation is significant at the 0.05 level (2-tailed).

** Correlation is significant at the 0.01 level (2-tailed).

t Correlation is significant at the 0.1 level (2-tailed). 
Table 5. Hierarchical Regression Analysis of Relationships between Bridging Social Capital and Regional Growth

\begin{tabular}{|c|c|c|c|c|c|c|c|}
\hline Model & $\begin{array}{l}\text { Outcome } \\
\text { variable }\end{array}$ & Step & Variable in the model & Beta & Adj. $R^{2}$ & $\mathrm{R}^{2}$ change & $\begin{array}{l}\text { Sig. F } \\
\text { change }\end{array}$ \\
\hline \multirow{2}{*}{ 1a } & \multirow{4}{*}{$\begin{array}{l}\text { LG (Regional } \\
\text { growth) }\end{array}$} & 1 & Control & & .233 & & .000 \\
\hline & & 2 & Add Density of vertical ties & -.013 & .220 & .013 & .913 \\
\hline \multirow{2}{*}{$2 a$} & & 1 & Control & & .233 & & .000 \\
\hline & & 2 & Add Density of horizontal ties & $.225^{*}$ & $.272^{*}$ & $.039 *$ & $.042^{*}$ \\
\hline \multirow{2}{*}{$3 a$} & \multirow{4}{*}{$\begin{array}{l}\text { LG (Regional } \\
\text { growth) }\end{array}$} & 1 & Control & & .233 & & .000 \\
\hline & & 2 & Add Strength of vertical ties & .001 & .220 & .013 & .996 \\
\hline \multirow{2}{*}{$4 a$} & & 1 & Control & & .233 & & .000 \\
\hline & & 2 & Add Strength of horizontal ties & $.210 \dagger$ & 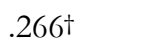 & $.033+$ & $.059 \dagger$ \\
\hline
\end{tabular}

$\mathrm{N}=65$; Control variables: age (LG), size (LN), and industry dummy;

${ }^{*} \mathrm{p}<.05 ;{ }^{\dagger} \mathrm{p}<.10$.

Hypotheses 1.1 and 1.2 were tested using hierarchical multiple regression analysis. A series of regressions were run to test the effects of various measures of bonding and bridging social capital on firm growth, while controlling for firm size, age, and industry. The first set of models was run to test relationships between variables of bridging social capital and the outcome variable (Table 5).

Firm age, size, and industry were entered at Step 1, explaining 23.2 percent (adjusted $\mathrm{R}$ square) of the variance in regional growth. Models $1 \mathrm{a}-2 \mathrm{a}$ tested the density of ties. Adding density of vertical ties did not improve model 1a. With the introduction of density of borizontal ties (model 2a), and after controlling for age, size, and industry, the model explained an additional 3.9 percent of the variance in growth. Adjusted $\mathrm{R}$ squared change $=3.98$ percent, $\mathrm{F}$ change $(1$, $60)=4.310, p<.042$. This variable was statistically significant, with a relatively small positive beta value (beta $=0.225, \mathrm{p}<.042$ ).

Models 3a-4a tested the strength of ties. Strength of vertical ties made no contribution for the growth outcome. Model 4 a tested strength of horizontal ties at Step 2, which has demonstrated the increase in total variance explained from 23.3 percent to 26.6 percent (adjusted R square), F $(4,60)=6.785, \mathrm{p}<.001$. The strength of horizontal ties resulted in an additional 3.6 percent of variance explained, and in $\mathrm{F}$ change $(1,60)$ $=3.702, \mathrm{p}<.059$. This variable was also statistically significant, with a small positive beta value (beta $=$ $210, p<.059)$. Since the density and strength of the horizontal ties were moderately correlated, it was not surprising to have similar results from direct effect tests. Post hoc power analysis using G-power soft- ware indicated that for this small sample of 65 firms, the power to detect obtained effects at .15 level of significance was .79 . This result is in line with Cohen's (1988) suggestion.

Hypothesis 1.1 predicted a positive relationship between bridging capital and regional growth. The results indicated that the density and strength of vertical ties had no effect on regional growth, but that the density and strength of horizontal ties had a small and significant positive direct effect on the outcome variable. Thus, Hypothesis 1.1 was partially supported. Both the structural (density) and relational (strength) dimensions of bridging social capital were essential for SME's ability to go beyond its local market. However, only horizontal ties were associated with SME geographic expansion. Vertical ties demonstrated no relation to SMEs growth outside its home market. It is possible that bridging horizontal and vertical ties serves different purposes for SMEs. While the former help in spanning boundaries, the latter provide stability in the uncertain environment of emerging markets. The extant literature tends to generalize all bridging ties of a firm as having similar effects, but it may be that further detalization is needed to clarify the role of horizontal and vertical linkages.

Table 6 reports regression results for the relationship between bonding social capital measured by trust and the SMEs' sales growth. Control variables entered at Step 1 explained 4.2 percent (adjusted R square) of the variance in sales growth. Adding the variable of trust at Step 2 demonstrated an increase in total variance explained from 4.2 percent to 5.7 percent (adjusted R square), F $(4,60)=1.963, \mathrm{p}<.15$. Trust resulted in additional 1.5 percent of variance 
Table 6. Hierarchical Regression Analysis of Relationships between Bonding Social Capital and SME Performance

\begin{tabular}{|c|c|c|c|c|c|c|c|}
\hline Model & $\begin{array}{l}\text { Outcome } \\
\text { variable }\end{array}$ & Step & Variable in the model & Beta & Adj. $R^{2}$ & $\mathrm{R}^{2}$ change & $\begin{array}{l}\text { Sig. F } \\
\text { change }\end{array}$ \\
\hline \multirow{2}{*}{$1 \mathrm{~b}$} & \multirow{2}{*}{ Sales growth } & 1 & Control & & .042 & & .135 \\
\hline & & 2 & Add Trust & $.174 \dagger$ & $.057 \dagger$ & $.015^{\dagger}$ & . $164 \dagger$ \\
\hline
\end{tabular}

$\mathrm{N}=65$; Control variables: age (LG), size $(\mathrm{LN})$, and industry dummy; ${ }^{\dagger} \mathrm{p}<.20$

explained, and in F change $(1,60)=1.982, \mathrm{p}<.17$. This variable was marginally significant, with a small positive beta value (beta $=0.170, \mathrm{p}<.17$ ). The statistical significance of trust is rather low.

However, for small samples (or small effect sizes) a more liberal "alpha" level is most appropriate for detecting a relationship or an effect (Stevens, 1996). For this sample, observed size effect and significance level of .2 statistical power was .75 ; it is lower than recommended .8 (Cohen, 1988).

Hypothesis 1.2 proposed a positive association between SME bonding social capital and sales growth. Test results give some indication that trust had a discreet and marginally significant direct effect on the outcome variable of sales growth. Bonding relations were associated with SME's sales growth as a measure of firm performance, providing cautious support for prior studies. Thus, bonding social capital contributed to efficiency of SME processes, and encouraged better performance. Hence, Hypothesis 1.2 was partially supported, provided that the variable of trust demonstrated a lower level of significance.

\section{Bonding and Bridging Social Capital of "Denatured" and "Traditional" SMEs}

A series of tests were performed to compare the facets of social capital of traditional and denatured SMEs. Hypotheses 2.1 and 2.2 predicted that parameters of bonding and bridging social capital were different for denatured SMEs, as compared to traditional SMEs. An independent samples t-test was performed in SPSS in order to compare mean scores for density of horizontal ties and trust as measures of bridging and bonding capital, respectively. A one-way multivariate analysis of variance (MANOVA) was considered for testing group differences, but dependent variables did not fully satisfy the requirements for multivariate analysis. MANOVA works best if dependent variables are highly negatively correlated, or moderately correlated in any direction; but this technique is not attractive if variables are highly positively correlated, or weakly correlated (Tabachnick \& Fidell, 2007). The latter is the case with measures of bonding and bridging capital that were almost uncorrelated. Thus, two independent samples t-tests were performed to test hypotheses about the build-up of social capital across different types of SME.

Prior to the application of this statistical technique, general assumptions of independence of variation, normality of distribution were checked for; and the homogeneity of variance was taken into consideration. Another consideration needs to be mentioned, which applies to the possibility of having nonsignificant results due to insufficient power. Stevens (1996) suggested that for small group sizes the "alpha" level of significance should be set at .1 or .15 in order to decrease the probability of a Type II error. Since the sample contained 65 observations, the approximate size of groups was from 20 (for 3 groups comparison) to 30 cases (for 2 groups), which put them in the "small size" category. The cut-off level of significance was set at .15 in order to capture a statistically significant difference between groups. The effect size was calculated to assess the relative magnitude of the differences, as suggested by Cohen (1988).

Independent samples t-tests found significant differences in mean scores of tested parameters of bonding and bridging social capital for denatured and traditional SMEs. There was a significant difference in scores of density of horizontal ties for denatured SMEs $(\mathrm{M}=4.55, \mathrm{SD}=1.15)$ and traditional SMEs $(\mathrm{M}=4.09, \mathrm{SD}=1.42 ; \mathrm{t}(63)=1.43, \mathrm{p}=.16$, twotailed). The magnitude of differences in the means (mean difference $=.46,95$ percent CI: -.19 to 1.11) was small (eta squared $=0.031$ ). Significant differences were also found for scores of trust, it was lower for denatured SMEs $(\mathrm{M}=15.8, \mathrm{SD}=2.9)$ than for traditional SMEs $(M=16.82, \mathrm{SD}=2.05 ; \mathrm{t}(63)$ $=1.65, \mathrm{p}=.10$, two-tailed). The magnitude of differences in the means for trust (mean difference $=$ 1.03, 95 percent CI: -.20 to 2.29 ) was also very small (eta squared $=0.041)$.

Overall, Hypothesis 2.1 was supported, as denatured SMEs had a slightly higher density of horizontal ties than traditional SMEs. Hypothesis 2.2 was supported, as scores for trust as the measure of bonding 
social capital were "significantly" higher for traditional SMEs than for denatured ones. For all the measures tested the effect size was small, meaning that only 3 percent of variance in density of horizontal ties, and 4 percent of variance in trust were explained by SME denaturing. The test results indicated that denatured SMEs had more horizontal ties to their business environment; and thus they may have been better positioned in terms of accessing new market or social opportunities than traditional SMEs. The latter group, on the other hand, had more trust among individuals in a firm; and thus traditional SMEs may have relied more on internal effectiveness, on firm-specific resources, and capabilities than their denatured counterparts. Post-hoc power analysis indicated that for groups of 34 and 31 firms, the power to detect these small effects at .15 level of significance was .55 (for trust) and .45 (for density of horizontal ties). This issue will be discussed further in the research limitations section.

\section{Discussion}

\section{Contributions}

Various perspectives on social capital research have provided many insights into the mechanisms of social capital formation and deployment. In a recent review of social capital research, Payne et al. (2011) have found that most of the studies were conducted at individual or network levels, with studies of organizational social capital receiving less attention. At the same time, organizational social capital has been studied mainly in terms of its tangible outcomes such as financial performance (Li, Zhou, \& Shao, 2009; Peng \& Luo, 2000; Park \& Luo, 2001).

First, this study not only adds to the less developed stream of organizational social capital research, but it also focuses at specific type of organizations (SMEs), and considers both tangible and intangible implications of social capital. Specifically, this study looks at firm-specific configuration of bonding and bridging social capital in relation to SME performance and geographic expansion. Thus, this paper attempts to provide more evidence regarding the role of firm-internal and firm-external social relations in SME development.

Second, this study adds more support for the role played by social capital in broader context of emerging markets. It is worth noticing that most of the studies of social capital focus on Asian countries, and the evidence from non-Asian context is rather fragmented. Hence, the most important contribution of this study is to shed more light on the value of social capital for small and medium enterprises operating outside the "Asian" group of emerging markets. Survey data collected in Russia contributes more empirical evidence for the less explored areas of firm strategic behavior in less structured environments such as emerging and transition economies. Choosing emerging markets as a research setting emphasizes the role of social capital as a valuable asset to the resource-restricted SMEs. And having empirical data from multiple countries helps generalizability of the social capital research.

Third, this research also contributes to the extant literature by providing more details on specific effects of bonding and bridging relational connections on SME growth outcomes. It was argued that greater bridging social capital would be associated with SME geographic growth, and that greater bonding social capital would be associated with better performance measured by sales growth. Based on the test results, bridging social relations seem to play an important role in helping SMEs move beyond their home region. In other words, external connections help to span boundaries of SME development, while internal bonding ties contribute to SME performance. Overall, this study extends the knowledge about the role of bonding and bridging relations in the context of smaller firms, and more turbulent environmental conditions. The results support the previously established positive association between horizontal bridging ties and growth. What is more important, this research brings into focus a meaningful distinction between the role of horizontal and vertical bridging connections. The results received for vertical bridging ties indicate that hierarchical, power-based relations are not important for building SMEs business networks and expanding geographically. The marginal effects of bonding social capital on SME performance prompt for clarification of the role played by bonding ties at the organizational level of analysis.

Finally, this study makes a contribution to the literature by linking the firm-specific configuration of bonding and bridging capital of SMEs to the nature of SMEs. Between-group comparisons of "traditional" and "denatured" SMEs were used to detect the differences in bonding and bridging capital across two groups of SMEs. As expected, significant variability in trust and in horizontal external ties was indicated for "traditional" and "denatured" SMEs. These groups exhibit distinct characteristics in terms of having more bridging or more bonding connections in their social capital. The findings regarding the higher density of horizontal bridging ties in "denatured" SMEs contribute to better understanding of relations between bridging social capital and strategies of SME development through exploration of market opportunities. It would be interesting to determine the causality of the relationship between the process of creation and the deployment of social capital and SME denaturing. 
Thus, present research 1) adds to the body of research on organizational social capital; 2) supports the value of social capital in emerging and transition economies; 3) emphasizes the role of horizontal bridging ties in facilitating SME development; and 4) poses the question of studying the structure of social capital in relation to distinct characteristics of organizations, including SMEs.

\section{Research Limitations}

The small sample size has limited the choice of analytical options available, and raised the question of the generalizability of the research findings. It also brought up the issue of limited statistical power in testing hypotheses related to social capital of "denatured" and "traditional" SMEs. The size of groups (N=34 and $\mathrm{N}=31)$ may have played a role in limiting the significance of between-group comparison. A post hoc power analysis revealed that on the basis of the mean, observed small effect size $(\mathrm{d}=.4)$ and alpha level of .05, a sample of approximately 260 firms would be needed to obtain statistical power at the recommended .8 level (Cohen, 1988).

Another issue in terms of research limitations relates to the fact that there was only a single informant per firm, so the answers to survey questions may be biased toward that person's view. However it is a common practice to only collect SME data from one source, and the questionnaires were filled in by either the CEO, or by another senior manager of a firm. Not all the data was self-reported. The dependent variables were objective measures of growth; and multiple sources were used for survey data verification.

Yet another potential limitation was the availability of appropriate measures of social capital at firm level. Payne et al. (2011) noted that operationalizations of social capital were inconsistent in extant literature. Indeed, the measures used in the prior research were not fully transferable to a firm level. And lastly, the study was cross-sectional, with no longitudinal considerations given to the relationship between social capital and growth. Thus, based on the issues listed above, the results should be taken with some caution.

\section{Theoretical Implications and Future Research}

This study extends our understanding of the specific role of bonding and bridging social capital for emerging market SMEs, and adds more support to the research on the importance of business networking for firm development. It also broadens our understanding of SME growth as both sales performance and geographical expansion. Moving this research forward it would be interesting to see if contextual factors will channel the process of development of firm's social capital. Bringing about the temporal perspective is worth testing if bonding and bridging facets of social capital change over time.

\section{Implications for Practice}

In addition to the theoretical contributions, this study provides important practical guidelines on the benefits of structural components of social capital. Namely, owners and managers of SMEs may benefit from a better understanding of the role played by bridging connections in fostering specific strategies of growth. Firms may pay more attention to the creation and maintenance of horizontal bridging ties if they intend to expand beyond their local market.

\section{Conclusion}

The present study has answered the question of whether bonding and bridging relational connections have specific effects on the growth outcomes of emerging market SMEs. The results suggest that both the density and the strength of bridging ties are associated with SMEs' expansion beyond their local "comfort zone". The study supports the role of firmexternal relations in spanning the boundaries of SME growth, and at the same time it brings to focus the difference between horizontal and vertical bridging ties. In addition to clarifying the association between social capital and SME growth, the results suggest that different classes of SMEs exhibit various levels of bonding and bridging social capital. Taken together, these findings contribute to an improved understanding of social capital and its outcomes for a firm across different institutional settings.

\section{References}

Abban, R., Omta, S. W. F., Aheto, J. B. K., \& Scholten, V. E. (2013). Connecting the dots: A multiple case study of the network relationships of small and medium-sized enterprises (SMEs) in the non-traditional agricultural export (NTAE) sector of Ghana. African Journal of Economic and Management Studies, 4(1), 74-94.

Adler, P. S., \& Kwon, S. (2002). Social capital: Prospects for a new concept. Academy of Management Review, 27, 17-40.

Assudani, R. H. (2009). Ethnic entrepreneurship: The distinct role of ties. Journal of Small Business and Entrepreneurship, 22(2), 197-206.

Baker, T., \& Nelson, R. (2005). Creating something from nothing: Resource construction through entrepreneurial bricolage. Administrative Science Quarterly, 50(3), 329-366.

Batjargal, B. (2007). Network triads: transitivity, referral and venture capital decisions in China and Russia. Journal of International Business Studies, 38, 998-1012. 
Boissevain, J. (1974). Friends of Friends, Networks, Manipulators and Coalitions. Oxford: Basil Blackwell.

Bonaccorsi, A. (1992). On the relationship between firm size and export intensity. Journal of International Business Studies, 23 (4), 605-635.

Burt, R. S. (1997). The contingent value of social capital. Administrative Science Quarterly, 42, 339-365.

Burt, R. S. (2000). The network structure of social capital. In R. I. Sutton and B. M. Staw (Eds.), Research in organizational behavior (pp. 345423). Greenwich, CT: JAI.

Burt, R. S., Hogarth, R. M., \& Michaud, C. (2000). The social capital of French and American managers. Organization Science, $11,123-147$.

Cao, Q., Simsek, Z., \& Zhang, H. (2010). Modeling the joint impact of the CEO and the TMT on organizational ambidexterity. Journal of Management Studies, 47(7), 1272-1296.

Calof, J. (1994). The relationship between firm size and export behaviour revisited. Journal of International Business, Studies, $25(2), 367-387$.

Cardoza, G., \& Fornes, G. (2011). The internationalization of SMEs from China: The case of Ningxia Hui Autonomous Region. Asia Pacific Journal of Management, 28(4), 737-759.

Chen, H., \& Chen, T. J. (1998). Network linkages and location choice in foreign direct investment. Journal of International Business Studies, 29 (3), 445-468.

Cohen, J. (1988). Statistical power analysis for the behavioral sciences. Hillsdale, NJ: Erlbaum.

Coleman, J. S. (1988). Social capital in the creation of human capital. American Journal of Sociology, 94, 95-120.

Collins, C. J., \& Clark, K. D. (2003). Strategic human resource practices, top management team social networks, and firm performance: The role of human resource practices in creating organizational competitive advantage. Academy of Management Journal, 46, 740-751.

Cooke, P., Clifton, N., \& Oleaga, M. (2005). Social capital, firm embeddedness and regional development. Regional Studies, 39 (8), $1065-1077$.

Coviello, N.E. (2006). The network dynamics of international new ventures. Journal of International Business Studies, $37(5), 713-731$.

Curran, J. (2006). "Specificity” and "Denaturing” the Small Business. International Small Business Journal, 24(2), 205-210.

D’Amboise, G. R., \& Muldowney, M. (1988). Management theory for small business: Attempts and requirements. Academy of Management Review, 13(2), 226-240.

Davidsson, P., Achtenhagen, L. \& Naldi, L. (2007). What do we know about small firm growth? In Z. J. Acs, \& D. B. Audretsch (Eds.), The Life Cycle of Entrepreneurial Ventures (p.p. 361-398). Springer US.

Davidsson, P., \& Wiklund, J. (2000). Conceptual and empirical challenges in the study of firm growth. In D. Sexton and H. Landström (Eds.), The Blackwell Handbook of Entrepreneurship (pp. 26-44). Blackwell Business, Oxford, MA.

De Clercq, D., Danis, W. M., \& Dakhli, M. (2009). The moderating effect of institutional context on the relationship between associational activity and new business activity in emerging economies, International Business Review, 19(1), 85-101.

Dyer, J. H. (1996). Does governance matter? Keiretsu alliances and asset specificity as sources of Japanese competitive advantage. Organization Science, 7(6), 649-666.

Florin, J., Lubatkin, M., \& Schulze, W. (2003). A social capital model of high-growth ventures. Academy of Management Journal, 46, $374-384$.

Galunic, D. C., \& Rodan, S. (1998). Resource combinations in the firm: Knowledge structures and the potential for Schumpeterian innovation. Strategic Management Journal 19(12), 1193-1201.

Gao, S. C., Sung, C. S., \& Zhang, J. (2012). Risk management capability building in SMEs: A social capital perspective. International Small Business Journal, 31(6), 677-700.

Gittins, T., Lang, R., \& Sass, M. (2015). The effect of return migration driven social capital on SME internationalisation: a comparative case study of IT sector entrepreneurs in Central and Eastern Europe. Review of Managerial Science, 9(2), 385-409.

Granovetter, M. S. (1973). The strength of weak ties. American Journal of Sociology, 78, 1360-1380.

Granovetter, M. S. (1992). Problems of explanation in economic sociology. In N. Nohria \& R. Eccles (Eds.), Networks and organizations: Structure form and action. (pp. 25-56). Boston: Harvard Business School Press.

Hyatt, D., \& Ruddy, T. M. (1997). An examination of the relationship between work group characteristics and performance: Once more into the breach. Personnel Psychology, 50, 553-585.

Iturrioz, C., Aragón, C., \& Narvaiza, L. (2015). How to foster shared innovation within SMEs' networks: Social capital and the role of intermediaries. European Management Journal, 33(2), 104-115.

Julien, P. -A. (1993). Small businesses as a research subject: Some reflections on knowledge of small businesses and its effects on economic theory. Small Business Economics, 5, 157-166.

Julien, P. -A., ed. (1998). The state of the art in small business and entrepreneurship, Introduction Chapter, Ashgate.

Khanna, T., \& Palepu, K. (1997). Why focused strategies may be wrong for emerging markets. Harvard Business Review, 75, 44-52.

Koka, B. R., \& Prescott, J. E. (2002). Strategic alliances as social capital: A multidimensional view. Strategic Management Journal, $23,795-817$. 
Kreiser, P. M., Patel P. C., \& Fiet, J. O. (2013). The influence of changes in social capital on firm founding activities. Entrepreneurship Theory and Practice, 37(3), 539-567.

Leana, C. R., \& Pil, F.K. (2006). Social capital and organizational performance: Evidence from urban public schools. Organization Science, 17(3), 353-366.

Leuz, C., \& Oberholzer-Gee, F. (2006). Political relationships, global financing, and corporate transparency: Evidence from Indonesia. Journal of Financial Economics, 81, 411-439.

Li, J. J., Zhou, K. Z., \& Shao, A. T. (2009). Competitive position, managerial ties, and profitability of foreign firms in China: An interactive perspective. Journal of International Business Studies, 40, 339-352.

Lowik, S., van Rossum, D., Kraaijenbrink, J., \& Groen, A. (2012). Strong ties as sources of new knowledge: how small firms innovate through bridging capabilities. Journal of Small Business Management, 50(2), 239-256.

Lu, J. W., \& Beamish, P. W. (2001). The internationalization and performance of SMEs. Strategic Management Journal, $22,565-586$.

Lumpkin, G. T., \& Dess, G. G. (1996). Clarifying the entrepreneurial orientation construct and linking it to performance. Academy of Management Review, 21, 135-172.

Ma, X., \& Wang, Y. (2012). Entrepreneurial Orientation, Social Capital, and the Internationalization of SMEs: Evidence from China. Thunderbird International Business Review, 54(2), 195-210.

Macneil, I. R. (1980). The new social contract. Yale University Press, New Haven, CT.

Manolova, T. S., Brush, C. G., Edelman L. F., \& Greene P. G. (2002). Internationalization of small firms: Personal factors revisited. International Small Business Journal, 20(1), 9-31.

Maurer, I., Bartsch, V., \& Ebers, M. (2011). The value of intra-organizational social capital: How it fosters knowledge transfer, innovation performance, and growth. Organization Studies, 32, 157-185.

May, R., Stewart, W., \& Sweo, R. (2000). Environmental scanning behavior in a transition economy: Evidence from Russia. Academy of Management Journal, 43, 403-428.

McCallum, S., \& O’Connell, D. (2009). Social capital and leadership development: Building stronger leadership through enhanced relational skills. Leadership \& Organization Development Journal, 30(2), 152-166.

McDougall, P. P., Shane, S., \& Oviatt, B. M. (1994). Explaining the formation of international new ventures: The limits of theories from international business research. Journal of Business Venturing, 9, 469-487.

McMillan, J., \& Woodruff, C. (1999). Interfirm relationships and informal credit in Vietnam. Quarterly Journal of Economics, 114, $1285-1320$.

Messeghem, K. (2003). Strategic entrepreneurship and managerial activities in SMEs. International Small Business Journal, $21(2), 197-212$.

Nahapiet, J., \& Ghoshal, S. (1998). Social capital, intellectual capital, and the organizational advantage. Academy of Management Review, 23(2), 242-266.

OECD. (2011). Classification of manufacturing industries into categories based on R\&D intensities. OECD.

Oviatt, B. M., \& McDougall, P. P. (1994). Toward a theory of new international ventures. Journal of International Business Studies, 25(1), 45-64.

Park, S. H., \& Luo, Y. (2001). Guanxi and organizational dynamics: Organizational networking in Chinese firms. Strategic Management Journal, 22, 455-477.

Payne, G. T., Moore, C. B., Griffis, S. E. \& Autry, C. W. (2011). Multilevel challenges and opportunities in social capital research. Journal of Management, 37(2), 491-520.

Pearson, A.W., Carr, J. C., \& Shaw, J. C. (2008). Toward a theory of familiness: A social capital perspective. Entrepreneurship Theory and Practice, 32(6), 949-968.

Peng, M. W., \& Heath, P. S. (1996). The growth of the firm in planned economies in transition: Institutions, organizations, and strategic choice. Academy of Management Review, 21, 492-528.

Peng, M. W., \& Luo, Y. (2000). Managerial ties and firm performance in a transition economy: The nature of micro-macro link. Academy of Management Journal, 43, 486-501.

Peng, Y. (2004). Kinship networks and entrepreneurs in China’s transitional economy. American Journal of Sociology, 109 (5), $1045-1074$.

Pennings, J. M., Lee, K., \& van Witteloostuijn, A. (1998). Human capital, social capital, and firm dissolution. Academy of Management Journal, 41(4), 425-440.

Penrose, E. (1959). The theory of the growth of the firm. Oxford University Press, Oxford.

Sako, M. (1992). Prices, quality and trust: Interfirm relations in Britain and Japan. Cambridge University Press, Cambridge, U.K.

Spicer, A., Kogut, B., \& McDermott, G. (2000). Entrepreneurship and privatization in central Europe: the tenuous balance between destruction and creation. Academy of Management Review, 25, 630-649. 
Stam, W., \& Elfring, T. (2008). Entrepreneurial orientation and new venture performance: The moderating role of intra- and extraindustry social capital. Academy of Management Journal, 51, 97-111.

Stevens, J. (1996). Applied multivariate statistics for the social sciences. Mahwah, NJ: Lawrence Erlbaum.

Tabachnick, B. S., \& Fidell, L. S. (2007). Using multivariate statistics, $5^{\text {th }}$ edition. Boston: Pearson/Allyn \& Bacon.

Tallman, S., Jenkins, M., Henry, N., \& Pinch, S. (2004). Knowledge, clusters, and competitive advantage. Academy of Management Review, 29, $258-271$.

Torrès, O., \& Julien, P.-A. (2005). Specificity and denaturing of small business. International Small Business Journal, $23,355-377$.

Tung, R. L., \& Chung, H. F. L. (2010). Diaspora and trade facilitation: The case of ethnic Chinese in Australia. Asia Pacific Journal of Management, 27(3), 37-392.

Uhlaner, L. M., Matser, I. A., Berent-Braun, M. M., \& Flören, R. H. (2015). Linking Bonding and Bridging Ownership Social Capital in Private Firms Moderating Effects of Ownership-Management Overlap and Family Firm Identity. Family Business Review, 28, $260-277$.

Uzzi, B. (1996). The sources and consequences of embeddedness for the economic performance of organizations. American Sociological Review, 61, 674-698.

Uzzi, B. (1997). Social structure and competition in interfirm networks: The paradox of embeddedness. Administrative Science Quarterly, 42 (1), 35-67.

van Staveren, I., \& Knorringa, P. (2007). Unpacking social capital in economic development: How social relations matter. Review of Social Economy, 65(1), 107-135.

Wiklund, J., \& Shepherd, D. (2003). Aspiring for, and achieving growth: The moderating role of resources and opportunities. Journal of Management Studies, 40(8), 1911-1941.

Woolcock, M. (1998). Social capital and economic development: Toward a theoretical synthesis and policy framework. Theory and Society, 27(2), 151-208.

Wright, M., Filatotchev, I., Hoskisson, R. E., \& Peng, M. W. (2005). Strategy research in emerging economies: Challenging the conventional wisdom. Journal of Management Studies, 42(1), 1-33.

Wu, F., Sinkovics, R. R., Cavusgil, S. T., \& Roath, A. S. (2007). Overcoming export manufacturers' dilemma in international expansion. Journal of International Business Studies, 38, 283-302.

Xin, K. R., \& Pearce, J. L. (1996). Guanxi: Connections as substitutes for formal institutional support. Academy of Management Journal, 39, 1641-1658.

Xu, K., Huang, K. -F., \& Gao, S. (2012). The effect of institutional ties on knowledge acquisition in uncertain environments. Asia Pacific Journal of Management, 29(2), 387-408.

Yiu, D. W., Lau, C. -M., \& Bruton, G. D. (2007). International venturing by emerging economy firms: The effects of firm capabilities, home country networks, and corporate entrepreneurship. Journal of International Business Studies, 38, 519-540.

Yli-Renko, H., Autio, E., \& Tontti, V. (2002). Social capital, knowledge, and the international growth of technology-based new firms. International Business Review, 11, 279-304.

Zahra, S. A., Ireland, R. D., \& Hitt, M. A. (2000). International expansion by new venture firms: International diversity, mode of market entry, technological learning, and performance. Academy of Management Journal, 43(5), 925-950.

Zahra, S., Neubaum, D. O., \& Naldi, L. (2007). The effects of ownership and governance on SMEs international knowledge-based resources. Small Business Economics, 29, 309-327.

Zhao, H., \& Hsu, C.-C. (2007). Local ties and foreign market entry: An empirical enquiry. Management International Review, 47(6), 815-830.

\section{Acknowledgment}

I am thankful to the special issue editor, Vishal K. Gupta, and the anonymous reviewers for their thoughtful comments that helped to strengthen my paper during the review process. This research has been presented at the Eastern Academy of Management 2015 Annual Meeting.

\section{About the Author}

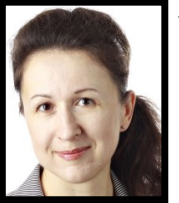

NATALYA TotsKayA (ntotskaya@laurentian.ca) received her PhD from Concordia University (Montreal, Canada). She is an Assistant Professor at the Faculty of Management, Laurentian University, Canada. Her research interests are in the area of social capital, emerging markets, and SME internationalization. 